\title{
Analyzing the Rise of Right-Wing Nationalism and Its Impact on US Foreign Policy
}

\author{
Mohammad A, Ismail \\ The University of Jordan, Jordan \\ E-mail: mkiswani2000@gmail.com
}

Received: Jan. 19, 2018 Accepted: Feb. 27, 2018 Online published: Mar. 3, 2018

doi:10.5296/jpag.v8i1.12507ＵRL: https://doi.org/10.5296/jpag.v8i1.12507

\begin{abstract}
The new regime after the 2016 General Election and its advisors are working to establish a white nationalist government in the United States. If their efforts are fruitful, the US and the world as a whole face an unpredictable future. However, a small degree of optimism exists as the process of regime transformation is in its formative phase and the consequences are yet to become apparent. Comprehending the foundation of this precarious course can contribute to the formulation of measures that can facilitate resistance to it, and promote the path to a progressive future. It is widely acknowledged that the rise of right-wing nationalism is not restricted in the US alone. Instead, nations such as Britain, Poland, and Russia have seen an emergence of politics centered on Conservative populism. The core premises of these Right-Wing movements underscore the importance of patriotism, take advantage of the public's reservations about minority races and denominations. Additionally, White nationalists are convinced that they can resolve existing economic challenges.

This paper focuses on how Right-wing nationalists infiltrated mainstream American politics to facilitate the election of an individual who subscribes to their principles in Donald Trump. In this case, the essay details the core factors that contributed to the rise of Conservative nationalists in the country. Furthermore, the essay assesses how Trump's White nationalist background is influencing his and the US' foreign policy. In this context, the paper explores Donald Trump's behavior on the international stage and his interactions with other world leaders. The paper concludes that Trump's White nationalist agenda is focused on altering the US foreign policy such that it promotes the Right-wing populism in Europe and supports despots in other parts of the world who can enter bilateral agreements that seek to advance US interests abroad.
\end{abstract}

Keywords: right-wing nationalism, Donald Trump, US foreign policy, white supremacy, neoliberalism, economic recession, conservative populism 


\section{Introduction}

The US is experiencing fundamental changes, and political analysts are already predicting a bleak future for the nation. Right-wing nationalist populism continues to grow throughout the US with the election of Donald Trump being the pinnacle of this movement (Michael, 2017). However, it is imperative to note that far-right movements have gained prominence throughout the West. For instance, in the UK, conservative nationalists were responsible for Brexit after engineering voters to reject Britain's membership to the European Union. In other nations, right-wing nationalists hold key government positions or even enjoy leadership status with examples being in Turkey, Hungary, Russia, and Poland (Inglehart \& Norris, 2016). Therefore, it can be stated that the choice of Donald Trump meant that even the leader of the 'Free World' belongs to the nationalist conservative wing.

Although right nationalist movements used to be antagonistic to each other, today, these organizations have better ties compared to what is reported. For instance, Stephen Bannon's Breitbart News is already trying to establish connections with France's leader of the Far-Right, Marie Le Pen as well as the Alternative for German. This aspect is made possible because these movements have common interests and objectives. The key tenets of right-wing nationalist movements in the US and across Europe center on their disdain for Black people, Muslims, immigration, feminism alongside other factors that seek to promote white supremacy (Kotz, 2017).

After the election of Donald Trump, whose campaign was centered on White nationalism ideology, the gravity of the far-right threat cannot be understated. Particularly, in the US, fundamental achievements in relation to labor and civil provision, women rights, ecological protection, as well as other social movements are in danger of being reversed. From an international relations' perspective, the ascension to power of an individual who campaigned on racist and anti-Islam principles may aggravate existing conflicts and the possibility of more antagonisms (Wodak, 2015). Based on this understanding, the primary focus of this essay is to analyze the growth of conservative nationalist populism in the US and its impact on the country's foreign policy.

\section{The Background of Right-Wing Nationalism in the US}

The platform on which Donald Trump's regime is built started as far as the late 1970s and the early 1980s. The transformation of the US capitalist structure from its regulated form after the Second World War to adopt neo-liberal principles set the stage for the rise of right-wing nationalism in the country. This fundamental paradigm shift repositioned the duty of the state in the economic set-up, capital-labor relationships, the corporate industry, and the country's dominant views (Kotz, 2017). Consequently, the government retracted its oversight role over commerce and finance, privatized civil amenities, reduced social welfare initiative, and transferred tax obligations from businesses and the wealthy to middle-class Americans.

While the changes identified were taking root in the United States, regulations controlling the world economy had been transformed to encourage the free transfer of products, amenities, and capital across national boundaries, resulting in a globally-connected economic setup 
(Gusterson, 2017). As such, the government and corporate executives reneged on the post-war capital-labor concessions and instead began sustained assaults against trade organizations resulting in the marginalization of collective bargaining. The outcome of this situation was the rise of jobs that required part-time or temporary employees. The concerted price determination that was favored by big business in the period leading up to this transition was replaced by uncontrolled competition (Wodak, 2015). As such, market principles were adopted in all echelons of the society, allowing the financial industry to blossom exponentially.

It is imperative to note that the dominant worldviews had changed before institutions and policies caught up. This point builds on the knowledge that this transformation began in the late 1960s and gathered pace throughout the 1970s with the rise of classical liberal notions being at the core, especially among economists (Inglehart \& Norris, 2016). In the years following World War II, policymakers believed that Keynesian ideologies were suited for the era resulting in the belief that capitalism was the best possible global economic framework. Furthermore, the Keynesian approach assumed that markets were self-regulatory, although it advocated for the minimal active participation of the government in shaping the economy. This view was validated by the belief that state involvement would help alleviate crises such as recessions, in addition to controlling income disparities, enhancing personal economic safety, and minimizing market catastrophes such as ecological destruction (Gusterson, 2017).

However, towards the end of the 1970s, a radical version of classical liberal ideologies had been instituted in place of Keynesian beliefs. The emerging neoliberal ideology held that personal liberty in relation to choice in the markets was the critical foundation of human welfare. From this perspective, the state was regarded as an enemy of individual freedom, a danger to private assets, and a leech thriving off the endeavor of individuals (Wodak, 2015).

The new kind of capitalism introduced proved to be strong. This perspective builds on the knowledge that for several years, it weathered all upheavals that were taking place in society, regardless of its dangerous implications for most citizens. Its robustness is further illustrated by the fact that it resisted change after the election of candidates who had promised to reverse neoliberal ideals once in office (Kotz, 2017). The examples include Bill Clinton in the US and Tony Blair in the UK who were elected in 1992 and 1997 respectively.

According to the proponents of neoliberalism in the US, the separation of government and business would create a scenario where private enterprise thrives, which would, in turn, drive the economic development. Therefore, a booming economy would ensure that all the people achieve prosperity even those that are located at the bottom of the income pyramid. Conversely, the analysis of market statistics showed that both investment and financial growth had stagnated compared to the controlled capitalism era. Furthermore, the much-expected growth did not come to fruition (Inglehart \& Norris, 2016). Instead, neoliberal reorganization led to enhanced revenues for big business and wages for the wealthy, while the employees' salaries followed a downward trajectory until the recession in 2007. The implication of these developments was a situation where a significant proportion of the populace saw their financial security decline, yet it appeared improbable to thwart the 
prevailing system. Therefore, several people and households offset the growing gaps in their budget through borrowing, which was safeguarded by asset surges in the stock market and the housing market. This move increased families' liquid wealth temporarily. However, it left the economy and the broader financial framework weak when the real estate sector collapsed in the year 2007 (Kotz, 2017).

The economic recession that began in the US in 2007 spread rapidly to other countries throughout the world. However, when big businesses such as General Motors and Goldman Sachs faced collapse, the elites changed tack concerning individual accountability and orchestrated bailouts to rescue these companies using public funds. However, for several homeowners facing foreclosure, the same urgency and consideration were not extended (Michael, 2017). After government intervention resolved this crisis, policymakers reverted to the same neoliberalism principles that had caused the recession in the pretext of austerity measures. However, this approach has resulted in economic stagnation with the yearly Gross Domestic Product growth in the US attaining a mean of 1-2 percent since the recovery commenced in 2009.

It is imperative to note that this stagnation, which is a multinational occurrence, mirrors the consequences of governmental austerity policies as well as the collapse of the neoliberal economic framework. This point is based on the belief that this model can no longer create the debt-financed consumer expenditure on which it has relied over the years. Furthermore, the issue of income disparities has worsened in recent years with all the small salary increments in the US going to the wealthy people (Kotz, 2017). Although companies are making profits, most enterprises have opted to save rather than reinvest this revenue.

For 25 years, the US society has been characterized by the gradual deterioration of public welfare, followed by massive crisis, and then economic torpor. The consequence of these happenings has been the destabilization of the political structure in the country, as well as in other nations across the globe. The erosion of the free market ideology means that the US public became more agitated against the affluent as well as individuals holding positions of power. This point explains the sudden gravitation towards socialist principles, especially among the younger generation (Gusterson, 2017). Therefore, by 2016, the US population was prepared to embrace an extreme deviation from the established norms.

In this context, it is essential to take into account the fact that a majority of the candidates that were favored by the ruling elite did not promise tangible solutions to the existing economic challenges. Furthermore, the two-party structure that had always forced politicians to pivot towards the center failed to play its obligation as a stabilizing agent. Consequently, the outlier, Donald Trump won the Republican nomination while the openly socialist, Bernie Sanders, almost won the Democratic ticket. These developments culminated in the election of Donald Trump who built his campaign on Right-Wing nationalist ideals to the presidency (Wodak, 2015).

However, it can be argued that the political phenomenon experienced in the US in 2016 is not new. Instead, the Great Recession of 1930 created a sustained period of economic unproductivity after an initial phase of free-market capitalism declined. The outcome of this 
stagnation was the rise of fascism in Germany, Italy, Spain, and Japan, while progressive reform of capitalism took root in the UK, France, and the US. On the other hand, the state-controlled socialism emerged in Central and East Europe (Michael, 2017). Therefore, it can be argued that the economic meltdown experienced in 2007 is behind the rise of right-wing nationalism in the US, Europe, and other isolated parts of the world.

\section{Donald Trump's Right-Wing Nationalist Foreign Policy}

So far, it has been difficult to outline Donald Trump's policy priorities because he continues to issue contradicting statements. This aspect can be explained by the element that his election platform was mainly extremist and unrealistic. For this reason, analyzing the American foreign policy today requires a critical review of Donald Trump's statements and behavior at the international stage (Payne, 2017).

In November 2017, the current US President cut short his five-nation Asian tour and returned home. He later wrote on Twitter, his favorite social media platform, that he had enjoyed the trip immensely. He added that he had made several friends at the highest level. This statement highlights the dominant theme of Donald Trump's international engagements. His government is focused on cultivating friendships instead of cutting deals. While in Asia, Trump told the Chinese President, Xi Jinping that their relationship was warm, and he hoped that their two countries would achieve great accomplishments together (Heer, 2018). Trump was similarly enthusiastic about Japanese Premier, Shinzo Abe.

From these illustrations, it is evident that President Trump favors bilateral diplomacy, and denounce alliance frameworks such as NATO and the United Nations sharply. Additionally, Trump opposes the hulking officialdom of the State Department. This aspect explains Trump's need to develop personal connections with other world leaders. He even describes rival countries from a personal perspective as proven by his angry tweets concerning North Korea's dictator, Kim Jong Un. From this perspective, it can be stated that Trump regards himself as the critical component of the US foreign policy under his administration (Heer, 2018). For this reason, he believes that good foreign policy is equivalent to having a healthy personal rapport with world leaders. This point explains why Donald Trump has worked in earnest to create a good relationship with Russia's Vladimir Putin. Additionally, some countries have recognized Trump's weakness and accord him the red-carpet treatment once he visits. This point is illustrated by the warm welcome he received when touring Saudi Arabia during his first official international tour as the US president that culminated in the signing of the biggest arms deal between the two countries. However, this agreement was viewed as more beneficial to the Saudi Arabians than it was to US interests in the region. From the analysis of Trump's visits to Asia, a clear theme that emerges is the abandonment of the US' soft power ideals in the global stage to the adoption of White nationalism ideals (Payne, 2017).

Throughout the modern US history, the country has succeeded in using soft war to advance its international agenda. Dating back to Woodrow Wilson's address in France that called for the formation of the League of Nations, to Barack Obama declaring that democracy is a universal doctrine in Cairo, the US presidents have often focused on engaging global citizens 
as opposed to speaking to presidents alone. However, in the case of the Trump's administration, it is evident that the current government does not have a clear human rights or democracy advancement plan to propagate (Michael, 2017). The only country he has admonished for its human rights' abuses is North Korea. However, to date, Trump is yet to speak on the military assault on the Rohingya tribal minority of Burma that belongs to the Islamic faith. The happenings in this Asian country have been described as the perfect illustration of ethnic cleansing by the United Nations. However, during his visit to Vietnam, Trump praised the country's communist leader, despite the fact that Hanoi is doubling down on free political speech and independent journalists. During the visit to Beijing, Trump spoke positively about the country's leader despite the fact that Xi Jinping oversees an autocratic regime that curtails press freedom and other human provisions. Finally, in the Philippines, Trump did not condemn the extrajudicial killings of suspect drug traffickers that were ordered by President Rodrigo Duterte. Furthermore, it was evident that throughout his Asian tour, President Trump did not engage the public directly at any forum (Heer, 2018).

Nonetheless, it is imperative to note that Trump is not incapable of leveraging soft power in instances where he deems it necessary. For example, last year, in July, the US President delivered a keynote speech in Poland declaring that he was willing to defend his household, liberty, country, and God. A more in-depth analysis of this speech reveals that it was a return to linguistic vanities that are synonymous with European and American Alt-Right movements (Heer, 2018). This address had undertones of historical populism as well as the current ones especially when Trump rallied his audience with a famous white nationalist phrase, 'We want God.' In this speech, it is evident that the God-revering citizens the US President was motivating in this address all reside in the White neighborhoods of Poland, Europe, and America. However, the hidden message in this speech was that the non-white people lacked the respect for the deity. The events that unfolded in the subsequent Independence Day celebrations after Trump's address demonstrate that the US President's speech left a mark on his audience. Over 60,000 people streamed through the streets of Warsaw in a demonstration led by nationalist movements whose core themes were anti-Semitism, and Islamophobia. Furthermore, chants such as 'White Europe of brotherly nations,' 'Europe will be White,' and 'We want God,' were heard (Payne, 2017).

The march in Poland is a clear explanation of why the US president overlooked the aspirations and worries of the Asian citizens. Principally, his soft authority agenda is focused on advancing the Right-wing White nationalism, which would not resonate with people of Asia. However, the current US President's reiteration of white nationalist ideas may resonate in other European nations such as Britain, Germany, and France that have seen a resurgence of nativist groups in recent years (Heer, 2017).

\section{Conclusion}

It is evident that the economic challenges afflicting the US due to the exhaustion of the neoliberal model of capitalism have promoted the rise of right-wing nationalism in the US. The election of Donald Trump was the embodiment of the spread of this movement because his campaign platform was built on White nationalism principles. The impact of Trump's 
presidency on the US international relations is the development of dual foreign policy. On the one hand, the US government is courting allegiance with White nationalist movements in Europe, which undermines democratically elected leaders who have been the US' longstanding allies in international issues. In contrast, the US has become friendly to the ruling elite in other parts of the globe including dictators and murderers, which goes against the conventional US values. If Trump's foreign policy succeeds, Europe is likely to be controlled by right-wing populists while Asians will be governed by despots open to entering bilateral trade agreements.

\section{References}

Gusterson, H. (2017). From Brexit to Trump: Anthropology and the rise of nationalist populism. American Ethnologist, 44(2), 209-214. https://doi.org/10.1111/amet.12469

Heer, J. (2018). Trump's White Nationalist Foreign Policy. New Republic. Retrieved 7 January 2018, from https://newrepublic.com/article/145814/trumps-white-nationalist-foreign-policy

Inglehart, R., \& Norris, P. (2016). Trump, Brexit, and the rise of populism: Economic have-nots and cultural backlash.

Kotz, D. (2017). The Specter of Right-Wing Nationalism. (2018). Jacobinmag.com. Retrieved 7 January 2018, from https://jacobinmag.com/2017/05/donald-trump-neoliberalism-right-wing-nationalism

Michael, G. (2017). The seeds of the alt-right, America's emergent right-wing populist movement. (2018). Salon. Retrieved 7 January 2018, from https://www.salon.com/2017/08/18/the-seeds-of-the-alt-right-americas-emergent-right-wingpopulist-movement_partner/

Payne, R. A. (2017). Trump and American Foreign Policy; A Threat to Peace and Prosperity?.

Wodak, R. (2015). The politics of fear: What right-wing populist discourses mean. Sage. https://doi.org/10.4135/9781446270073

\section{Copyright Disclaimer}

Copyright for this article is retained by the author(s), with first publication rights granted to the journal.

This is an open-access article distributed under the terms and conditions of the Creative Commons Attribution license (http://creativecommons.org/licenses/by/4.0/). 